\title{
Spectrophotometric Determination of Hydroxyurea in Pharmaceutical Preparations
}

\author{
Ferial M. EL-Samman \\ Department of Chemistry/ College of Science/ University of Mosul
}

(Received 9/4/2014; Accepted 12 / 6/2018)

\begin{abstract}
A simple spectrophotometric method for the determination of hydroxyurea has been developed. The method is based on the oxidation of hydroxyurea with iron(III) in acidic medium, and the liberated iron(II) reacts with 1,10-phenanthroline to form the orange-red chelate which has a maximum absorption at $510 \mathrm{~nm}$. Beer's law is obeyed over the concentration range 5-160 $\mu \mathrm{g}$ of hydroxyurea in a final volume of $25 \mathrm{ml}$, with a molar absorptivity of $2.36 \times 10^{4} 1 . \mathrm{mol}^{-1} \cdot \mathrm{cm}^{-1}$ and Sandell's sensitivity index of $0.0032 \mu \mathrm{g} . \mathrm{cm}^{-2}$, a relative error of -2.4 to $+1.6 \%$ and a relative standard deviation of \pm 0.32 to $\pm 1.5 \%$, depending on the concentration level. Interferences due to excipients have been examined. The proposed method has been applied successfully to the determination of hydroxyurea in pharmaceutical formulations (capsules).
\end{abstract}

Keywords: Hydroxyurea, Iron(III), 1,10-Phenanthroline, Spectrophotometry, Pharmaceutical analysis.

\section{القدير اللميف للهيروكسي يوربا في المستخضرل الصيدلانية}

\section{الملهص}

يتضمن البمث طريقة طيفية بسيطة لقدير الهيدروكسي يوريا وتعتمد الطريقة على للكسة الهيدروكسي يوريا بولنطة الحديد الثلاثي في وسط حلمضي ومفاعلة الحيد الثنائي الناتج مع كلثف 10,1 فينانثرولين لتكوين معقد برنقالي محمر والذي يوني له أقصى لمتصاص عند الطول الموجي 510 نانوميتر. حيث أمكن طبيق قانون بير في مدى التركيز (5 -160) مايكروغرله

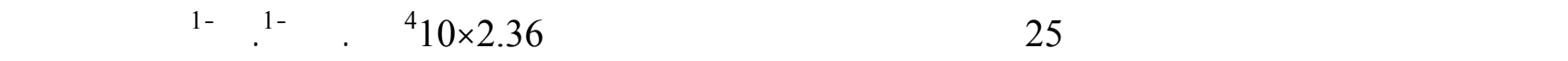

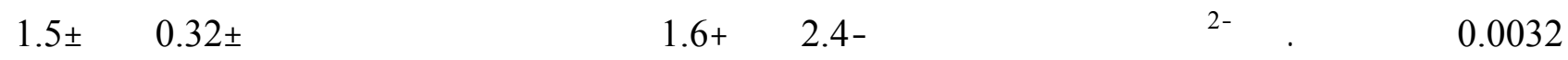
اعتمادا على مستوى التركيز وم ظبيق الطريقة في تقدير الهيدروكسي يوريا في مستحضرات دوائية (الكبسول). الكاملت الدالة: الهيدروكسي يوريا، الحديد الثلاث، 10,1 فينانثرولين، القدير الطيف، المستحضرات الصيدلانية.

\section{INTRODUCTION}

Hydroxyurea (or hydroxycarbamide) belongs to a group of medicines called antineoplastic medicines, which interfere with the growth of cancer cells, and it is mainly used in chronic myelogenous leukemia. However, hydroxyurea is used in combination chemotherapy and it is also effective as an adjunct with radiation therapy for head and neck cancer also it has shown some clinical efficacy against renal, ovarian and prostat cancers (Ashenbrenner et al., 2002; Baer and Williams, 1996). Hydroxyurea has recently approved for treatment of adults with recurrent sickle cell crises, it acts to increase the production of fetal hemoglobin which prevents the polymerisation of deoxy sickle cell hemoglobin (Steinberg et al., 2011; Lanzkron et al., 2008; Brunton et al., 2011; Katzung et al., 2012). 
Different techniques have been reported for the determination of hydroxyurea. These include high performance liquid chromatography with electrochemical detection (Jong et al., 2003; Manouilov et al., 1998; Rodriguez et al., 2014) and gas chromatography-mass spectrometry (Kettani, 2009) for the determination of hydroxyurea in human plasma (Legrand et al., 2017) as well as the determination of hydroxyurea in capsules and biological fluids by ion-selective potentiometry and fluorimetry (El-Kosasy, 2003). Another method is the analysis of hydroxyurea by proton nuclear magnetic resonance (NMR) spectroscopy has also been proposed (Main et al., 1987). Though all of these methods are highly sensitive, main disadvantages are the necessity of expensive and sophisticated instrumentation.

Literature survey reveals that few spectrophotometric methods have been reported for the determination of hydroxyurea, these methods are based on the chromogenic reaction of hydroxyurea with a variety of reagents, for example, pentacyanoamine ferrate, nitroprussideferricyanide and p-dimethylaminobenzal -dehyde (Main et al., 1987), and recently, 2,2'-bipyridyl and pottasium ferricyanide chromogenic reagent have been suggested for assay of hydroxyurea in capsule (Majid and Bashir, 2013; Mahmood, 2013). The currently official method of analysis for hydroxyurea is a titrimetric procedure, the compound is oxidized with excess iodine and the unreacted iodine is then titrated with thiosulfate, using starch indicator (British Pharmacopeia, 1980).

The present work describes a visible spectrophotometric method for the determination of hydroxyurea, based on its oxidation with iron(III) and subsequent chelation of the iron (II) with 1,10-phenanthroline to form the well-established tris-iron(II) chelate the colour intensity of which is directly proportional to the amount of hydroxyurea originally present in solution.

\section{EXPERIMENTAL}

\section{Apparatus:}

Spectral and absorbance measurements are carried out using shimadzu UV-Visible recording spectrophotometer UV-160, with 1-cm matched glass cells.

electrode.

The $\mathrm{pH}$ measurements are performed using Philips PW $9420 \mathrm{pH}$ meter with a combined

\section{Reagents and chemicals:}

Chemicals used are of analytical reagent grade.

Working hydroxyurea $(50 \mu \mathrm{g} / \mathrm{ml})$ solution. A $0.01 \mathrm{~g}$ of hydroxyurea is dissolved in distilled water and the volume is completed to $200 \mathrm{ml}$ in a volumetric flask.

1,10-phenanthroline $\left(2 \times \mathbf{1 0}^{-2} \mathrm{M}\right)$ solution. It is prepared by dissolving $1.176 \mathrm{~g}$ of the hydrochloride monohydrate salt of the compound in distilled water and diluting to $250 \mathrm{ml}$ in a calibrated flask.

Iron (III) $\left(2.5 \times 10^{-2} \mathrm{M}\right)$ solution. This solution is prepared by diluting the stock ferric chloride solution (Hopkin and Williams) to the required concentration after the addition of few drops about $0.4 \mathrm{ml}$ of concentrated nitric acid solution per $250 \mathrm{ml}$ final solution.

Sodium fluoride (0.4 M) solution. This solution is prepared by dissolving $4.2 \mathrm{~g}$ in distilled water and diluting to $250 \mathrm{ml}$.

\section{Capsules}

The contents of four capsules are weighed powdered and mixed (each capsule contains , 500 $\mathrm{mg}$ hydroxyurea), an accurately weighed amount of powder equivalent to $0.01 \mathrm{~g}$ hydroxyurea is dissolved in about $50 \mathrm{ml}$ distilled water the solution is stirred and filtered, then the volume is completed to $200 \mathrm{ml}$ with distilled water in a volumetric flask to prepare a solution of $50 \mu \mathrm{g} . \mathrm{ml}^{-1}$ hydroxyurea.

\section{Procedure}

Aliquots of samples solution containing 5- $160 \mu \mathrm{g}$ of hydroxyurea (0.2-6.4 ppm when diluted to $25 \mathrm{ml}$ ) are transferred separately into a series of $25 \mathrm{ml}$ calibrated flasks, to each flask $1 \mathrm{ml}$ of iron (III) solution is added and mixed thoroughly then $1 \mathrm{ml}$ of 1,10-phenanthroline solution followed by 
$1 \mathrm{ml}$ of sodium fluoride solution after which the volumes are completed to the mark with distilled water. The absorbance are measured at $510 \mathrm{~nm}$ against the reagent blank solution using $1-\mathrm{cm}$ cells.

\section{RESULTS AND DISCUSSION}

The spectrophotometric properties of the colord product as well as the different experimental parameters affecting the color development and its stability are carefully studied and optimized. For the following experiments, $50 \mu \mathrm{g}$ of hydroxyurea is taken in a final volume of $25 \mathrm{ml}$.

\section{Absorption spectra}

When hydroxyurea is treated according to the recommended procedure, the iron(II)-1,10phenenthroline complex exhibits an absorption maxima at $510 \mathrm{~nm}$ (Fig.1) in contrast to the reagent blank which shows slight absorption at this wavelength. The color is formed immediately and is stable for at least 120 minutes.

The calibration graph is linear over the concentration range 0.2-6.4 ppm (Fig. 2). The molar absorptivity has been found to be $2.36 \times 10^{4} 1 . \mathrm{mol}^{-1} \cdot \mathrm{cm}^{-1}$.

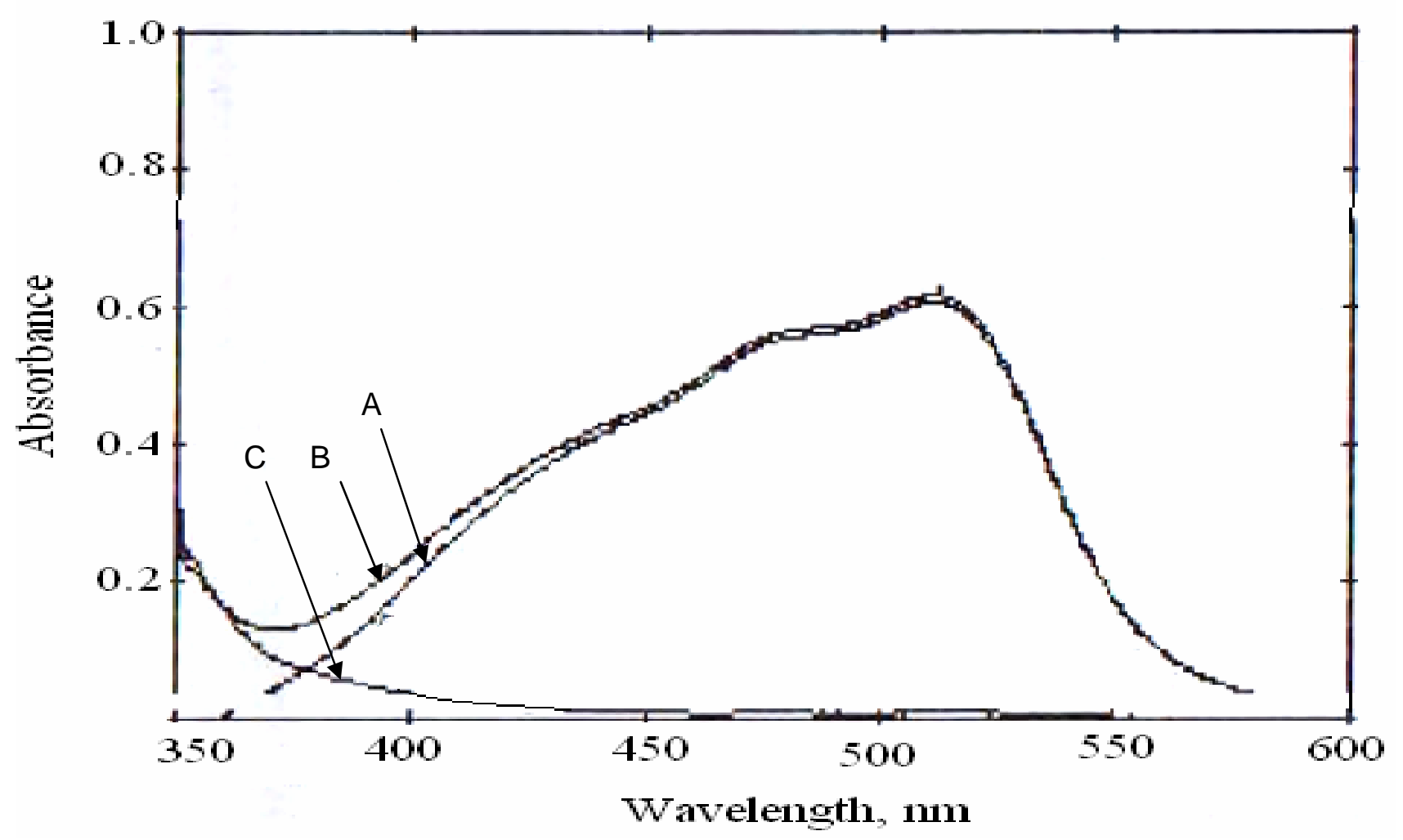

Fig. 1: Absorbance spectra of $50 \mu \mathrm{g}$ hydroxyurea measured against (A) reagent blank (B) distilled water and $(C)$ reagent blank measured against distilled water. 


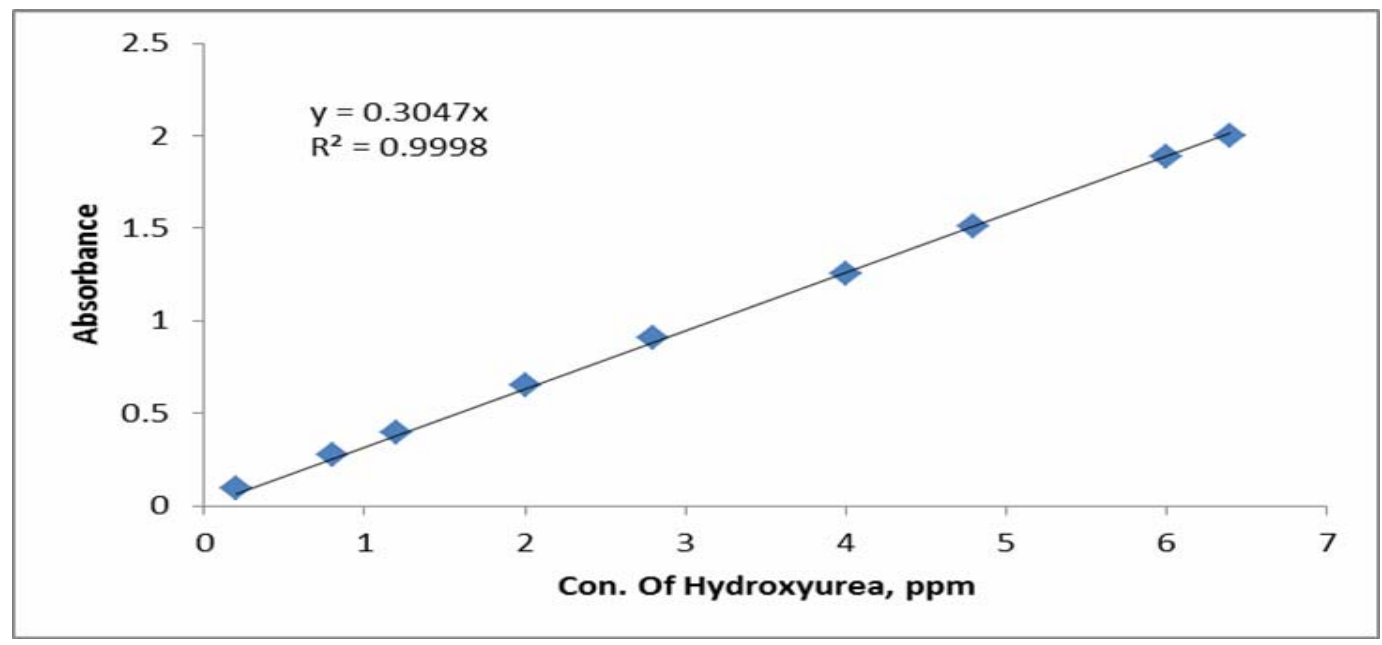

Fig. 2: Calibration graph for hydroxyurea using the proposed method

\section{Effect of $\mathrm{pH}$ on reduction}

Different amount $(1-7 \mathrm{ml}$ of $0.1 \mathrm{M})$ of various acids $\left(\mathrm{HCl}, \mathrm{H}_{2} \mathrm{SO}_{4}\right.$ and $\left.\mathrm{HClO}_{4}\right)$ have been examined for the redox reaction between hydroxyurea and iron (III), the results indicate that there is a decrease in color intensity and stability of the complex formed. Hydroxyurea reduces iron(III) in acidic medium at a $\mathrm{pH}$ ranging from (1.8-3) at which color intensity has a constant maximum absorbance.

For $\mathrm{pH}$ values less than 1.8 (by addition of $0.1 \mathrm{M} \mathrm{HCl}$ ) or higher than 3 (by addition of $0.1 \mathrm{M}$ $\mathrm{NaOH})$ this causes a decrease in color intensity.

Four buffer solutions of $\mathrm{pH} 3$ with different composition have been tested, formic acid-NaOH,

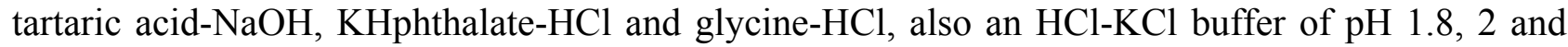
2.2 are examined for their effect on color intensity and stability.

The experimental data show that the absorbance is the same whether these buffers are present

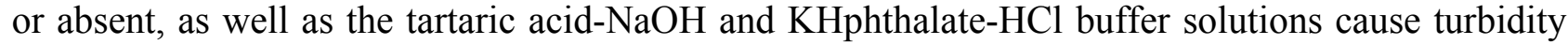
after their addition. The components of reaction mixture in the reduction step are acidic already $(\mathrm{pH} \approx 2.5)$ and addition of acid or buffer solution is not recommended and the $\mathrm{pH}$ of final reaction mixture is about 4 which is within the range to give the constant maximum absorbance for the iron (II)-phenanthroline complex (Christian, 2004).

\section{Effect of iron (III) amount}

Hydroxyurea is allowed to react with different amounts $\left(0.5-5 \mathrm{ml}\right.$ of $\left.2.5 \times 10^{-2} \mathrm{M}\right)$ of iron (III) solution. The results show that 1-3 $\mathrm{ml}$ of iron (III) solution gives a constant maximum absorbance. The color intensity of the complex formed decreases slightly with an increase in amount of iron (III) solution as shown in Table 1 . So a volume of $1 \mathrm{ml}$ of $2.0 \times 10^{-2} \mathrm{M}$ ferric chloride solution, considered to be optimum and is selected for the subsequent experiments.

Table 1: Effect of iron (III) amount on absorbance

\begin{tabular}{|c|c|c|}
\hline \multirow{2}{*}{ ml of iron (III) solution $\left(\mathbf{2 . 5} \times \mathbf{1 0}^{-\mathbf{2}} \mathbf{M}\right)$} & \multicolumn{2}{|c|}{ Absorbance } \\
\cline { 2 - 3 } & Hydroxyurea $\mathbf{( 5 0} \boldsymbol{\mu g})$ & Blank \\
\hline 0.5 & 0.620 & 0.01 \\
\hline 1 & 0.624 & 0.019 \\
\hline 2 & 0.623 & 0.032 \\
\hline 3 & 0.622 & 0.037 \\
\hline 4 & 0.613 & 0.042 \\
\hline 5 & 0.605 & 0.049 \\
\hline
\end{tabular}




\section{Effect of 1,10-phenanthroline reagent}

Different volumes $\left(0.5-4 \mathrm{ml}\right.$ of $\left.2.0 \times 10^{-2} \mathrm{M}\right)$ of 1,10 -phenanthroline solution are added while the other conditions kept constant following the general procedure. The absorbance of the reaction mixture is constant when (1-4 ml) of the reagent solution is used. However, using $1 \mathrm{ml}$ of the reagent is satisfactory, since the absorbance of the corresponding reagent blank solution increases slightly on using larger volumes of the reagent solution, the results its are given in Table 2 .

Table 2: Effect of the reagent amount on absorbance

\begin{tabular}{|c|c|c|}
\hline \multirow{2}{*}{$\begin{array}{l}\text { ml of } 1,10 \text {-phenanthroline } \\
\text { solution }\left(2 \times 10^{-2} \mathrm{M}\right)\end{array}$} & \multicolumn{2}{|c|}{ Absorbance } \\
\hline & Hydroxyurea $(50 \mu \mathrm{g})$ & Blank \\
\hline 0.5 & 0.618 & 0.012 \\
\hline 1 & 0.625 & 0.02 \\
\hline 2 & 0.624 & 0.023 \\
\hline 3 & 0.623 & 0.027 \\
\hline 4 & 0.625 & 0.029 \\
\hline
\end{tabular}

\section{Effect of sodium fluoride}

The effect of sodium fluoride concentration on the absorbance is studied, amounts from (0.5-5 ml) of $0.4 \mathrm{M}$ sodium fluoride solutions are examined. The investigations show that (1-3 ml) of sodium fluoride solution give maximum absorbance and $1 \mathrm{ml}$ of sodium fluoride is chosen for the subsequent experiments.

Sodium fluoride in addition to its masking effect of the excess iron (III) solution, it decreases the absorbance of the blank value and increases the absorbance of the colord system.

Sodium fluoride solution must be added after the addition of the chromogenic reagent because if it is added before 1,10-phenanthroline, a decrease in color intensity is noticed.

\section{Effect of temperature}

The effect of temperature on the color intensity has been studied. The absorbance remains the same at room temp. or after heating the final reaction mixture in a water-bath at $\left(40-60 \mathrm{C}^{\circ}\right)$ either before addition of the reagent or after its addition. So the reaction is carried out at room temperature.

\section{Nature of the reaction between hydroxyurea and iron (III) ion}

Job's method has been used in the determination of the reaction ratio of hydroxyurea with iron (III) ion. The results show that a 1:2 hydroxyurea to iron (III) ion ratio is obtained.

The probable mechanism might be the following:

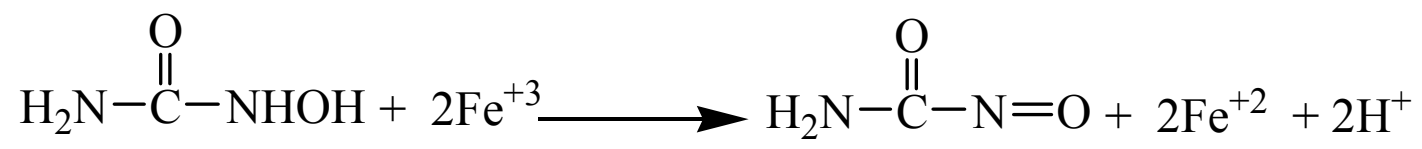

\section{Hydroxyurea}

\section{Interferences}

In order to realize the analytical application of this method effects of some common excipients which often accompany the pharmaceutical preparations have been studied by carrying out the determination of $50 \mu \mathrm{g}$ hydroxyurea in the presence of each of the interferent using the recommended procedure. The results are given in (Table 3 ). 
Table 3: Effect of excipients on the determination of $50 \mu \mathrm{g}$ hydroxyurea

\begin{tabular}{|c|c|c|}
\hline \multirow{2}{*}{ Excipient } & Amount added, $\boldsymbol{\mu g}$ & Recovery, \% \\
\hline \multirow{2}{*}{ Glucose } & 100 & 99.67 \\
\cline { 2 - 3 } & 500 & 100.98 \\
\hline \multirow{2}{*}{ Lactose } & 100 & 99.67 \\
\cline { 2 - 3 } & 500 & 100.82 \\
\hline \multirow{2}{*}{ Starch } & 100 & 101.3 \\
\hline \multirow{2}{*}{ Gum acacia } & 500 & 102.46 \\
\cline { 2 - 3 } & 100 & 101.97 \\
\hline \multirow{2}{*}{ Povidone (polyvinylpyrrolidone) } & 500 & 102.13 \\
\hline \multirow{2}{*}{$\mathrm{NaH}_{2} \mathrm{PO}_{4}$} & 100 & 100.98 \\
\hline \multirow{2}{*}{$\mathrm{Na}_{2} \mathrm{HPO}_{4}$} & 500 & 100.82 \\
\hline \multirow{2}{*}{$\mathrm{Citric}_{4}$ acid } & 100 & 100.82 \\
\cline { 2 - 3 } & 500 & 100.32 \\
\hline \multirow{2}{*}{ Magnesium stearate } & 100 & 102.3 \\
\hline & 500 & 100.98 \\
\hline \multirow{2}{*}{} & 100 & 101.15 \\
\hline & 500 & 103.61 \\
\hline
\end{tabular}

The results in table indicate that the studied foreign compounds (excipients) do not interfere in the determination of hydroxyurea using the proposed method.

\section{Analysis of pharmaceutical preparations}

Application of the proposed method to the determination of hydroxyurea in its dosage forms is successfully made, the results are presented in Table 4 . The excellent recoveries obtained indicate a good agreement between the amount of hydroxyurea present and that measured by the proposed procedure.

Table 4: Application of the proposed method for the determination of hydroxyurea in pharmaceutical preparations

\begin{tabular}{|c|c|c|c|c|c|}
\hline \multirow{2}{*}{$\begin{array}{c}\text { Pharmaceutical } \\
\text { preparations }\end{array}$} & \multicolumn{2}{|c|}{ Hydroxyurea, $\boldsymbol{\mu g}$} & \multirow{2}{*}{ R.E $^{*}$ (\%) } & \multirow{2}{*}{ Recovery $^{*}$ (\%) } & \multirow{2}{*}{ RSD $^{*}$ (\%) $^{*}$} \\
\cline { 2 - 5 } & Taken & Found & & 101.29 & 0.76 \\
\hline Hydrea & 20 & 20.26 & 1.29 & 100.59 & 0.77 \\
\cline { 2 - 6 } 500 mg/capsule & 50 & 50.29 & 0.59 & 100.17 & 0.32 \\
\cline { 2 - 6 } Squibb(England) & 100 & 100.19 & 0.17 & 97.75 & 1.11 \\
\hline Hydroxyurea & 20 & 19.55 & -2.25 & 97.6 & 0.37 \\
\cline { 2 - 6 } 500 mg/capsule & 50 & 48.8 & -2.4 & 98.3 & 1.51 \\
\cline { 2 - 6 } Filaxis (Argentina) & 100 & 98.3 & -1.7 & 101.6 & 0.4 \\
\hline Ninadroxyurea & 20 & 20.32 & 1.6 & 100.66 & 0.49 \\
\cline { 2 - 6 } 500 mg/capsule & 50 & 50.33 & 0.66 & 100.32 & 0.88 \\
\cline { 2 - 6 } & 100 & 100.32 & 0.32 & & \\
\hline
\end{tabular}

* Average of five determinations.

\section{Accuracy and precision}

To check the accuracy and precision, hydroxyurea in capsules has been determined at three different concentrations. The results are shown in Table 4 and indicate that the method is satisfactory. 


\section{Comparison of the methods and t-test}

A comparison between the present method and British pharmacopoeia standard method (British Pharmacopoeia, 1980) for the determination of hydroxyurea in three drugs, is based on the t-test (Christian, 2004) to show the ability of using the present method in the determination of investigated drugs Table 5.

Table 5: Comparison of the methods and experimental t-test values

\begin{tabular}{|c|c|c|c|}
\hline \multirow{2}{*}{ Drug } & \multicolumn{2}{|c|}{ Recovery* (\%) } & \multirow{2}{*}{ t.exp } \\
\cline { 2 - 3 } & Present method & $\begin{array}{c}\text { British pharmacopoeia } \\
\text { Method }\end{array}$ & \multirow{2}{*}{0.055} \\
\hline Hydrea (Squibb) & 100.67 & 99.96 & 0.501 \\
\hline Hydroxyurea (Filaxis) & 97.87 & 98.7 & 0.122 \\
\hline Ninadroxyurea (N.D.I) & 100.71 & 100.38 & \multirow{2}{*}{} \\
\hline
\end{tabular}

* Average of five determinations.

The tabulated $t$ value for eight degrees of freedom $\left(\mathrm{N}_{1}+\mathrm{N}_{2}-2\right)$ at the $95 \%$ confidence level is 2.306. The results in Table 5 show that the $t$ value is lessthan the critical value, indicating no significant difference between the proposed method and the standard method.

Table 6, shows the comparison between some of analytical variables obtained from the present method with that of a recent spectrophotometric methods.

Table 6: Comparison of the methods

\begin{tabular}{|c|c|c|}
\hline Analytical parameters & Present method & Literature method* \\
\hline $\mathrm{pH}$ & $<4$ & 2.6 \\
\hline Temperature $\left({ }^{\circ} \mathrm{C}\right)$ & At room temperature & At room temperature \\
\hline Development time (minutes) & Directly & 10 \\
\hline$\lambda_{\max }(\mathrm{nm})$ & 510 & 522 \\
\hline Stability of the colour (minutes) & 120 & 35 \\
\hline Principle reagent & 1,10-phenanthroline & 2,2'-bipyridyl \\
\hline Beer's law range (ppm) & $0.2-6.4$ & $0.25-7.5$ \\
\hline $\begin{array}{c}\text { Molar absorptivity } \\
\left(1 . \mathrm{mol}^{-1} . \mathrm{cm}^{-1}\right)\end{array}$ & $2.36 \times 10^{4}$ & $1.65 \times 10^{4}$ \\
\hline RSD $(\%)$ & \pm 0.32 to \pm 1.5 & \pm 0.9 \\
\hline Colour of the dye & Orange -red & Pink-red \\
\hline Nature of the dye & $1: 2$ & $1: 4$ \\
\hline Application of the method & $\begin{array}{l}\text { Determination of hydroxyurea in } \\
\text { capsules }\end{array}$ & $\begin{array}{l}\text { Determination of hydroxyurea in } \\
\text { capsule }\end{array}$ \\
\hline
\end{tabular}

* (Majid and Bashir, 2013)

The results indicate that the proposed method has a good sensitivity compared with the above literature method.

\section{CONCLUSION}

The proposed method permits rapid, precise and accurate determination of hydroxyurea with an application to pharmaceutical analysis. The short analysis time and low cost are the main advantages of this method for routine analysis in quality control. 


\section{REFERENCES}

Ashenbrenner, D.S.; Cleveland, L.W; Venable, S.J. (2002). "Drug Therapy in Nursing". Lippincott Williams and Wilkins, Philadelphia, $902 \mathrm{p}$.

Baer, C.L.; Williams, B.R. (1996). "Clinical Pharmacology and Nursing". $3^{\text {rd }}$ ed., Springhouse, USA, $1222 \mathrm{p}$.

British Pharmacopoeia. (1980). Her Majesty's Stationary Office, London.

Brunton, L.; Chabner, B.; Knollman, B. (2011). The pharmacological basis of therapeutics, $12^{\text {th }}$ ed., McGraw-Hill, New York, 1721 p.

Christian, G.D. (2004). "Analytical Chemistry". $6^{\text {th }}$ ed., J. Wiley and Sons, New York, pp. 765, 83.

El-Kosasy, A.M. (2003). Determination of hydroxyurea in capsules and biological fluids by ionselective potetiometry and fluorimetry. J. AOAC Intern., 86, 15-21.

Jong, Y.J.; Hsu, H.O.; Wu, H.L.; Kou, H.S.; Wu, S.M. (2003). Analysis of hydroxyurea in human plasma by high performance liquid chromatography with electrochemical detection. Anal. Chim. Acta , 488, 223-230.

Katzung, B.G.; Masters, S.B.; Trevor, A.J. (2012). "Basic and Clinical Pharmacology". 12 ${ }^{\text {th }}$ ed., McGraw-Hill, New York, 582 p.

Kettani, T.; Cotton, F.; Gulbis, B.; Ferster, A.; Kumps, A. (2009). Plasma hydroxyurea determined by gas chromatography-mass spectrometry. J. Chromatogr. B, 877, 446-450.

Lanzkron, S.; Strouse, J.J.; Wilson, R. (2008). Systematic review: Hydoxyurea for the treatment of adults with sickle cell disease. Ann. Intern. Med., 148(12), 939-955.

Legrand, T.; Rakotoson, M.G.; Galacteros, F.; Bartolucci, P.; Hulin, A. (2017). Determination of hydroxyurea in human plasma by HPLC-UV using derivatization with xanthydrol. $J$. Chromatogr. B Analyt. Technol. Biomed. Life Sci., 1064, 85-91.

Mahmood, R.N. (2013). Analytical uses of prussian blue complex to assay of hydroxyurea in capsule form. Thesis of High Diploma, University of Mosul, College of Science, $12 \mathrm{p}$.

Main, K.B.; Medwick, T.; Bailey, L.C.; Shinkal, J.H. (1987). Quantitative analysis of hydroxyurea and urea by proton nuclear magnetic resonance, (NMR) spectroscopy. Pharm. Res., 4, 412, and references therein.

Majid, Z.W.; Bashir, W.A. (2013). Indirect spectrophotometric assay of hydroxyurea with its pharmaceutical application as capsules. J. Raf. Sci., 24(2), 53-64.

Manouilov, K.K.; McGuire, T.R.; Gwilt, P.R. (1998). Colorimetric determination of hydroxyurea in human serum using high performance liquid chromatography. J. Chromatogr. B: Biomed. Sci. Appl., 708, 321-324.

Rodriguez, A.; Beukens, D.; Debouge, N.; Gulbis, B.; Cotton, F. (2014). Development and validation of a liquid chromatography method with electrochemical detection for hydroxyurea quantification in human plasma and aqueous solutions. J. Chromatogr. Sep. Tech., 5, 244-247.

Steinberg, M.H.; Zhi-Hong, L.; Barton, F.B.; Terrin, M.L.; Charache, S.; Dover, G.J. (2011). Fetal hemoglobin in sickle cell anemia: determinants of response to hydroxyurea. Blood $J$. Hematol. Library. Org., 28, 1078-1088. 